\title{
Short-Term Interactive Effects of Experimental Heat Waves and Turbidity Pulses on the Foraging Success of a Subtropical Invertivorous Fish
}

\author{
Bruno R. S. Figueiredo ${ }^{1} * \mathbb{E}$, Clementina Calvo ${ }^{2}$, Anahí López-Rodríguez ${ }^{2}$, Roger P. Mormul ${ }^{3} \mathbb{D}$, \\ Franco Teixeira-de Mello ${ }^{2}$, Evanilde Benedito ${ }^{3}$ and Mariana Meerhoff ${ }^{2,4}$ \\ 1 Departamento de Ecologia e Zoologia, Universidade Federal de Santa Catarina (UFSC), \\ Florianópolis 88040-970, SC, Brazil \\ 2 Departamento de Ecología y Gestión Ambiental, Centro Universitario Regional del Este, Universidad de la \\ República (UDELAR), Maldonado 20000, Uruguay; clemen.calvo@gmail.com (C.C.); \\ alopez@fcien.edu.uy (A.L.-R.); frantei@fcien.edu.uy (F.T.-d.M.); merluz@fcien.edu.uy (M.M.) \\ 3 Programa de Pós-graduação em Ecologia de Ambientes Aquáticos Continentais, Universidade Estadual de \\ Maringá (UEM), Maringá 87020-900, PR, Brazil; roger.mormul@gmail.com (R.P.M.); \\ eva@nupelia.uem.br (E.B.) \\ 4 Department of BioScience, Aarhus University, 8000 Aarhus, Denmark \\ * Correspondence: bruno.figueiredo@ufsc.br; Tel.: +55-48-3271-6161
}

Received: 1 August 2019; Accepted: 6 October 2019; Published: 10 October 2019

\begin{abstract}
Sudden increases in temperature and turbidity in aquatic ecosystems are expected for different regions in the future, as a result of the more frequent extreme climatic events that are predicted. The consequences of these abrupt changes in the outcomes of predator-prey interactions are unknown. Here, we tested the effects of a heat wave and a turbidity pulse on the foraging success of a subtropical cichlid fish (Gymnogeophagus terrapurpura) on amphipods (Hyalella curvispina). We carried out a short-term experiment combining treatments of turbidity ( 3 and 100 nephelometric turbidity units [NTU]) and water temperature $\left(19.2,22.2,25.2\right.$ and $\left.27.0^{\circ} \mathrm{C}\right)$, considering potential differences given by fish length. Changes in water temperature did not promote significant changes in prey consumption. Higher turbidity, in contrast, decreased prey consumption. Also, we found that fish with different body lengths consumed a similar amount of prey under clear waters, but, in turbid waters, bigger individuals were more efficient than the smaller individuals. This finding is an empirical demonstration that the effect of increased turbidity on predation rate depends upon predator body size, and it suggests that bigger body sizes may help overcome turbidity-associated limitations in finding and capturing prey. Our short-term results suggest that, if turbidity pulses and heat waves become more frequent in the future, the outcome of fish-invertebrate interaction can be affected by local characteristics such as fish population size distribution.
\end{abstract}

Keywords: water transparency; warming; predation; predator-prey interaction

\section{Introduction}

Climate change scenarios and models make varied predictions for different locations around the world. Increases in the average temperature and also in the frequency of extreme temperatures and rainfall events are expected in many regions [1,2], and particularly in the tropical and subtropical regions [3,4]. Such environmental changes may affect several processes at different spatial, temporal and biological scales [5], including the predator-prey encounter and predation rates [6]. This is because increases in temperature can increase energetic demands, especially of ectothermic organisms such as fishes and most aquatic invertebrates $[7,8]$. As a result of increased water temperature, fish can increase 
the area searched in pursuit of prey and enhance their foraging success [9-11]. Although diel and seasonal changes in temperature can trigger physiologically-regulated acclimation mechanisms [12,13], extreme temperatures (e.g., summer heat waves) can critically jeopardise the overall performance of an organism [14,15], not least in interaction with other potential stressors. For example, it has been shown that while small changes in water temperature have little or no impact on the predator ability to encounter their prey $[11,16]$, heat waves can promote massive prey consumption, destabilising the consumer-resource interactions across trophic levels [17]. For prey, such as aquatic invertebrates, increases in water temperature may change their survival rate depending on the balance between the temperature-dependent escape speed of the prey and the temperature-dependent attack speed of the predator [16].

Extreme rainfall events usually increase surface runoff from the catchment to water bodies, promoting terrestrial soil washout and increased turbidity in surface freshwater ecosystems [18]. Many floodplains, lakes and rivers, particularly in tropical and subtropical regions, experience sudden increases in inorganic turbidity following a pulse event in a tributary $[19,20]$, which may have substantial effects on different aspects of predator-prey interactions [21]. As turbidity reduces the visual field of visually-oriented organisms [22], changes in turbidity may affect encounter, attack and predation rates [23,24]. A reduction in underwater visibility may, however, make predators increase their swimming activity to compensate for a lower probability of finding prey $[25,26]$. For prey, increases in water turbidity may impact their survival rate depending on the degree of dependence from visual cues of predators and prey to detect each other $[27,28]$. Given that heat waves and rainfall-induced turbidity pulses are predicted to become longer, more intense and more frequent $[1-4,18,29]$, understanding the response of aquatic predators (e.g., fish) and prey (e.g., macroinvertebrates) to extreme temperatures and to altered sensory conditions such as with an increase in turbidity will provide valuable information about the potential consequences of such environmental changes for aquatic organisms and potentially for ecosystem functioning.

Individual responses of predator and prey performances to environmental changes may also vary with their respective thermal performances, age, condition, and other individual traits such as body size $[30,31]$. For predators, capture success is strongly dependent on their relative body size [32-35]. Therefore, short-term increases in water temperature could disproportionally enhance the activity of bigger predators. Similarly, if some visually oriented predators increase their swimming activity in turbid waters [25,36], bigger predators may be expected to increase it further. Therefore, the outcome of a particular predator-prey interaction will depend on the environmental dependence of both predator and prey performances modulated by individual traits.

Here, we experimentally tested the interactive effects of short-term increases in water temperature and turbidity, mimicking heat waves and turbidity pulses, on the foraging success of a subtropical cichlid fish, accounting for variations in fish length. We hypothesised that the effects of water temperature and turbidity on predation are not independent, but are modulated by predator body size. We expected that the highest foraging success would occur in clear and warmer waters, and would be particularly high in the case of the larger individuals.

\section{Materials and Methods}

\subsection{Studied Species and Animal Collection}

We used Gymnogeophagus terrapurpura Loureiro, Zarucki, Malabarba and González-Bergonzoni 2016, (Perciformes: Cichlidae) as the predator and Hyalella curvispina Shoemaker 1942 (Crustacea: Amphipoda) as the prey. We choose G. terrapurpura because it is one of the most abundant fish in Uruguayan aquatic systems [37,38]. It has a wide distribution throughout the lower Uruguay River basin (in south-eastern South America, subtropical climate), where it has been recorded in different habitats including shallow lakes, floodplain lakes, rivers, and streams [39]. The standard length of G. terrapurpura ranges between 10 and $92 \mathrm{~mm}[37,39]$, and it reaches maturity (adulthood) at the 
age of 1 to 2 years, measuring around $55 \mathrm{~mm}$ [40]. This small cichlid is also representative of the most common fishes in the Neotropical region, where fish assemblages are primarily composed of small-sized species, which use vision as their primary source of environmental information [37,41,42]. Also, G. terrapurpura is an omnivore-invertivore, feeding on zooplankton, macroinvertebrates and periphyton $[38,43]$. Feeding activity is sharply reduced during the autumn and winter when water temperature decreases $[43,44]$.

Specimens of G. terrapurpura were caught in summer in Diario lake (a shallow coastal lake, in the southeast of Uruguay, $34^{\circ} 90^{\prime} 41^{\prime}$ 'S, $55^{\circ} 00^{\prime} 82^{\prime \prime} \mathrm{W}$, water temperature $\approx 19^{\circ} \mathrm{C}$ ) using non-lethal electrofishing gear $(n=70$, standard length $=69.1 \pm 6.6 \mathrm{~mm}$ and fresh weight $=13.7 \pm 4.2 \mathrm{~g}$; mean \pm standard deviation). We searched for fish that were adults, thus avoiding those shorter than $55 \mathrm{~mm}$ long, and checked for vivid and dark colours in the ventral part of the head, typical of adult individuals [39]. We used only adult individuals to disentangle the potential effects of variations in predator body size from the effects of ontogenetic variation in feeding performances [45]. After sampling, individuals were transported to the nearby university facilities (Maldonado, Uruguay), where they were individually added to the experimental units (aquaria) and kept until the end of the experiments.

Hyalella curvispina were collected from littoral aquatic plant roots in a sub-urban stream $\left(34^{\circ} 88^{\prime} 67^{\prime \prime}\right.$ $\mathrm{S}, 54^{\circ} 95^{\prime} 24^{\prime \prime} \mathrm{W}$, Aparicio stream) in Maldonado, Uruguay, near the laboratory facilities ( $\mathrm{n}=1680$, body length $=4.1 \pm 0.7 \mathrm{~mm}$ ). Sampled amphipods were kept in $600 \mathrm{ml}$ bottles (20 individuals per bottle) containing stream water until the experiment (housing lasted no longer than two days). We chose this amphipod species because it has a wide distribution across freshwater habitats of South America [10], where it often reaches very high densities, and it plays a key role in subtropical aquatic food webs by feeding on phytobenthos and processing organic matter [46]. Also, amphipods are one of the most important food items of Gymnogeophagus spp. [38,43,47].

\subsection{General Experimental Design}

In a total of four temperature and light controlled rooms, we performed two connected experiments: The first to assess potential differences in prey behaviour associated with predator presence and temperature increase (hereafter, 'prey behaviour experiment'); and the second to understand the short-term effects of increases in temperature and turbidity levels on the foraging success of $G$. terrapurpura (hereafter, 'foraging success experiment').

The fish were added (one per aquarium) to rectangular aquaria (width $=25 \mathrm{~cm}$; length $=30 \mathrm{~cm}$; height $=50 \mathrm{~cm}$; water volume $=20 \mathrm{~L}$; all sides covered with a dark cloth to avoid mutual visual influence) and kept for over a week to acclimate to the experimental conditions (light regime 12:12 hours and increasing temperature as appropriate for each treatment).

In the 'prey behaviour experiment', we combined two experimental water temperatures (19.2 and $27.0^{\circ} \mathrm{C}$ ) with the presence and absence of one G. terrapurpura. In the 'foraging success experiment', we crossed four water temperature treatments $\left(19.2,22.2,25.2\right.$ and $\left.27.0^{\circ} \mathrm{C}\right)$ and two turbidity levels (clear water, 3 nephelometric turbidity units [NTU]) and turbid water, 100 NTU). The experimental temperatures were chosen based on the average temperature in Uruguayan shallow aquatic systems, which may vary between $19{ }^{\circ} \mathrm{C}$ and $25^{\circ} \mathrm{C}$ in early summer [48,49], plus a $2{ }^{\circ} \mathrm{C}$ increase in the average temperature, as predicted for the Rio de la Plata basin in the next 50 years [3]. The chosen turbidity levels have been reported for many aquatic systems in the Rio de la Plata basin; the highest level is observed after strong precipitation events [50]. Such events are also predicted to become more frequent in this region in the next 50 years [3].

In both experiments, all treatments were assigned at random to the aquaria (i.e., the experimental unit), and all treatments had seven replicates. Each aquarium was filled with $20 \mathrm{~L}$ of dechlorinated water (initial water temperature $\approx 19^{\circ} \mathrm{C}$, initial turbidity $\approx 3 \mathrm{NTU}, \mathrm{pH}=8.64$, conductivity $=1222 \mu \mathrm{S} \mathrm{cm}{ }^{-1}$ ). The mean body length of $G$. terrapurpura did not differ significantly neither among the temperature (one-way ANOVA $F_{3,48}=0.79 ; P=0.51$ ) nor the turbidity treatments (one-way ANOVA $F_{1,48}=0.17$; 
$P=0.68$ ). Fish were acclimated to warmer waters through a gradual increase of water temperatures (an increase of $1{ }^{\circ} \mathrm{C}$ per day until it reached the target temperature) to reduce fish stress. Amphipods were exposed to room temperature 1 hour before the beginning of the experiments. All experimental water temperature levels were reached $24 \mathrm{~h}$ before the beginning of the experiment. The fish were fed with commercial dry fish food during the first four days, and three days before the experiment, fish were starved to stimulate the consumption of amphipods. The experimental units were aerated, but the aeration systems were removed before the beginning of the experiment to facilitate the location of both predator and prey.

Twenty amphipods were then introduced to each aquarium. The experiments (and the co-occurrence between fish and amphipods) lasted for 1 hour. This experimental time was chosen to keep the turbidity level as homogenous as possible (i.e., varying no more than $10 \%$ ) from the beginning to the end of the experiment.

\subsection{Experiment \#1: Assessment of Prey Behaviour in Experimental Clear Water Conditions}

In the 'prey behaviour' experiment, all four treatments were run with clear water conditions: (i) absence of predator at $19.2{ }^{\circ} \mathrm{C}$; (ii) absence of predator at $27^{\circ} \mathrm{C}$; (iii) presence of predator at $19.2{ }^{\circ} \mathrm{C}$ and (iv) presence of predator at $27^{\circ} \mathrm{C}($ total $n=28)$. Aquaria were filled with $30 \mathrm{~L}$ of dechlorinated water. Fish were acclimated to experimental conditions, following the protocol described above. After adding the amphipods to the aquaria, some of them left the aquarium water and remained on the walls. Then, after 1 hour of the experiment, we counted the number of amphipods that climbed up the aquaria walls in each experimental unit to assess whether such behaviour was associated to the predator presence (being a predator avoidance behaviour) or to warmer waters (being a temperature-mediated stress avoidance behaviour).

\subsection{Experiment \#2: Effects of Heat Waves and Turbidity Pulses on Fish Foraging Success}

In the 'foraging success' experiment, the potential short-term effects of increases in temperature and in water turbidity on foraging success of $G$. terrapurpura were assessed crossing four water temperature treatments $\left(19.2,22.2,25.2\right.$ and $27.0^{\circ} \mathrm{C}$ ) with two turbidity levels (3 NTU and $\left.100 \mathrm{NTU}\right)$, in a fully crossed factorial design (total $n=56$ ). Turbidity was generated by the addition of previously collected and sun-dried clay to dechlorinated water. However, fish were not acclimated to water turbidity since we wanted to test the response to a sudden increase in inorganic turbidity mimicking a pulse event in a tributary. One hour before the beginning of the experiment, each experimental unit (already containing one fish and $20 \mathrm{~L}$ of clear water) received either $10 \mathrm{~L}$ from a $1000 \mathrm{NTU}$ turbid water solution or $10 \mathrm{~L}$ from clear water, in order to achieve the desired turbidity (i.e., 100 NTU or 3 NTU) and standardise the disturbance, respectively. The turbidity levels were measured using a multi-parameter water quality checker (U-50, Horiba, Kyoto, Japan).

After 1 hour, fish were removed and killed with an overdose of the anaesthetic eugenol $\left(4 \mathrm{~mL} \mathrm{~L}^{-1}\right.$ of a solution of 1:10 eugenol: $95 \%$ ethanol), weighed and measured, according to the guidelines of the Honorary Commission for Animal Research in Uruguay (CHEA, protocol \#658 CEUA-Maldonado). The water from each aquarium was filtered through a plankton net ( $65 \mu \mathrm{m}$ mesh size), to count the number of surviving prey. Counting the number of amphipods that climbed up the aquaria walls at the end of experimental time (U), allowed us to calculate the number of amphipods that remained inside the water (i.e., the number of prey available for predation; $\mathrm{N}=20-\mathrm{U}$ ) in each treatment.

We calculated the foraging success of G. terrapurpura (\% FS), disregarding the amphipods that were unavailable to predation $(\mathrm{U})$, as follows: 


$$
\% \text { FS }=\frac{P}{N} \times 100
$$

where $\mathrm{P}$ is the number of amphipods eaten, and $\mathrm{N}$ the number of available amphipods $(\mathrm{N}=20-\mathrm{U})$. We thereafter used 'foraging success' as the response variable in the statistical analyses.

\subsection{Data Analysis}

\subsubsection{Experiment \#1: Assessment of Prey Behaviour in Experimental Clear Water Conditions}

We applied a two-way ANOVA test, testing the main and interactive effects of water temperature (19.2 and $27.0^{\circ} \mathrm{C}$ ) and predation risk (absence and presence of G. terrapurpura) on the number of amphipods that left the aquaria water after one hour (response variable). Data transformation was not required, because the assumptions of normal distribution and homogeneity of variances were met. In case of significant differences, we applied the Tukey test for pairwise post-hoc comparisons.

\subsubsection{Experiment \#2: Effects of Heat Waves and Turbidity Pulses on Fish Foraging Success}

To detect significant differences in the number of amphipods available for predation $(\mathrm{N})$ among treatments, we applied a two-way ANOVA test with permutations, using the lmPerm package [51]. The permutational approach was applied because this response variable was not normally distributed even when transformed [51].

With a general linear model (GLM), we tested the effects of water temperature (four levels: 19.2, 22.2, 25.2 and $27.0^{\circ} \mathrm{C}$ ) and turbidity (two levels: clear and turbid) on the foraging success of G. terrapurpura, adjusting for the potential effect of fish length (standard length, $\mathrm{cm}$, used as a continuous predictor variable). The assumptions of normality and homoscedasticity were met, and data transformation was not required. We tested for the significance of the slopes derived from the relationship between the response variables (i.e., foraging success) and the continuous predictor variable (i.e., fish length) for each main factor (i.e., water temperature and turbidity) level, through a t-test of the angular coefficient $[52,53]$. Our hypothesis that the interactive effects of water temperature and turbidity on predation varied with predator body size would not be rejected if the interaction of the variables 'water temperature' and 'turbidity' and the co-variable 'fish length' was significant. The analyses were carried out using the softwares $\mathrm{R}$ and Statistica with the level of significance set at $P<0.05$.

\section{Results}

\subsection{Experiment \#1: Assessment of Experimental Prey Behaviour in Clear Water Conditions}

In the treatments with fish, many amphipods left the aquarium water and remained on the walls (see column Amphipods out of water in Table 1), a response that did not significantly occur in the treatments without fish (Table 1). Also, without predators, a similarly low number of amphipods left the aquarium water in the cold $\left(19.2^{\circ} \mathrm{C}\right)$ and warm waters $\left(27^{\circ} \mathrm{C}\right)$ (post-hoc comparisons, Table 1$)$, but the response of amphipods to the presence of predators was slightly more pronounced in the warm than in cold waters (significant interaction term, Table 1). Therefore, this amphipod response, although enhanced by higher temperatures, may be considered a behaviour to avoid the co-occurrence with the predator (i.e., a predator avoidance behaviour) in our experimental setup. 
Table 1. Analysis of variance (two-way ANOVA) testing the effects of predator presence, water temperature and their interaction on the number of amphipods leaving the aquarium water (interpreted as experimental predator avoidance). The median and the average number of amphipods out of the water, the standard deviation and the results of the Tukey post-hoc test are shown. Different letters in the 'Post-hoc comparison' column indicate statistically significant differences among the treatments.

\begin{tabular}{|c|c|c|c|c|}
\hline Effects & Degrees of Freedom & Means of Squares & $F$ & $P$ \\
\hline Fish presence (FP) & 1 & 0.82 & 235.58 & $<0.001$ \\
\hline Water temperature (WT) & 1 & 0.11 & 30.80 & $<0.001$ \\
\hline Interaction $\mathrm{FP} \times \mathrm{WT}$ & 1 & 0.05 & 15.58 & $<0.001$ \\
\hline Error & 24 & 0.01 & & \\
\hline \multicolumn{2}{|c|}{ Treatment Combination } & \multicolumn{2}{|l|}{$\begin{array}{l}\text { Amphipods out of Water } \\
\text { Median (Mean } \pm \text { SD) }\end{array}$} & Post-hoc Comparison \\
\hline Fish absent at $19.2^{\circ} \mathrm{C}$ & \multicolumn{3}{|c|}{$1(0.9 \pm 0.7)$} & a \\
\hline Fish absent at $27.0^{\circ} \mathrm{C}$ & \multicolumn{3}{|c|}{$2(1.6 \pm 0.5)$} & $\mathbf{a}$ \\
\hline Fish present at $19.2^{\circ} \mathrm{C}$ & \multicolumn{3}{|c|}{$6(5.9 \pm 0.9)$} & b \\
\hline Fish present at $27.0^{\circ} \mathrm{C}$ & \multicolumn{3}{|c|}{$9(9.7 \pm 1.7)$} & c \\
\hline
\end{tabular}

\subsection{Experiment \#2: Effects of Heat Waves and Turbidity Pulses on Fish Foraging Success}

The number of $H$. curvispina that left the aquaria as a response to predator presence was alike at all temperatures: $19.2{ }^{\circ} \mathrm{C}$ (median, mean \pm SD: $\left.4,4.2 \pm 2.4\right), 22.2^{\circ} \mathrm{C}(3,3.5 \pm 2.4), 25.2{ }^{\circ} \mathrm{C}(3,3.8 \pm 3.3)$ and $27.0^{\circ} \mathrm{C}(6,6.5 \pm 3.4)\left(F_{3,48}=2.55 ; P=0.07\right)$. In the same way, the number of $H$. curvispina out of the water did not significantly differ between clear $(3,3.4 \pm 2.7)$ and turbid waters $(5,4.8 \pm 3.0)$ (ANOVA $\left.F_{1,48}=0.80 ; P=0.38\right)$. Also, we found no significant interaction between water temperature and turbidity on the experimental anti-predator response of $H$. curvispina $\left(F_{3,48}=0.26 ; P=0.86\right)$. Therefore, the number of prey available for predation was similar in all treatments.

The model including 'water temperature', 'turbidity' and 'fish length' and their interactions explained $77 \%$ (adjusted $R^{2}$ value; $F_{15,40}=13.506 ; P<0.001$ ) of the variation found in the foraging success of G. terrapurpura (Table 2). Foraging success was significantly higher in the clear than in the turbid waters ( $93 \pm 6 \%$ vs $73 \pm 7 \%$, respectively; Figure 1$)$. However, the negative effect of turbidity on the foraging success of G. terrapurpura was influenced by fish length (Table 2; Figure 2). Bigger fish had greater foraging success than the smaller individuals, but only in turbid waters, while no significant relationship between fish length and foraging success occurred in clear waters (Table 2; Figure 1). In contrast, we found no significant effect of water temperature on the foraging success of $G$. terrapurpura. The foraging success of $G$. terrapurpura was similar at $19.2^{\circ} \mathrm{C}(86 \pm 9 \%), 22.2{ }^{\circ} \mathrm{C}(83 \pm 13 \%), 25.2^{\circ} \mathrm{C}$ $(82 \pm 13 \%)$ and $27^{\circ} \mathrm{C}(81 \pm 13 \%)$. No significant interaction with fish length occurred (Table 2; Figure 1).

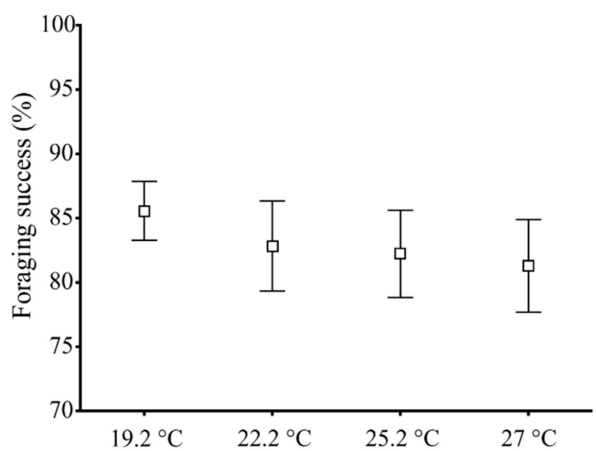

(a)

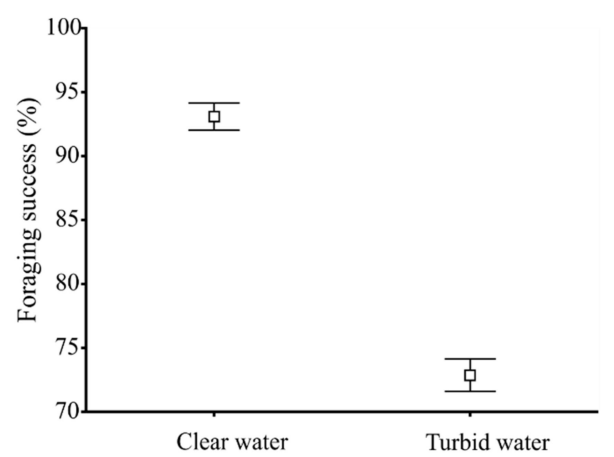

(b)

Figure 1. The main effects of temperature and turbidity on the foraging success of Gymnogeophagus terrapurpura on Hyalella curvispina, at different water temperatures (a), in clear (3 NTU) and turbid water (100 NTU) (b). Data show mean and standard errors, after pooling the data from the levels of the factor not shown. Foraging success was significantly higher in clear than in turbid waters (b), while no significant effect of water temperature on the foraging success of G. terrapurpura was detected (a). 


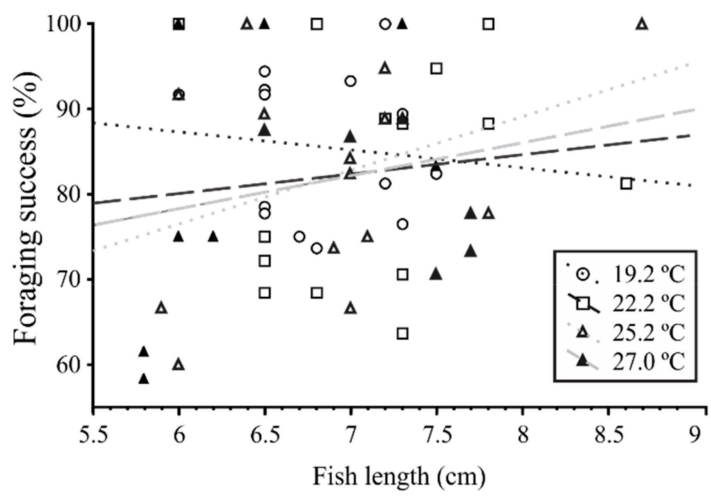

(a)

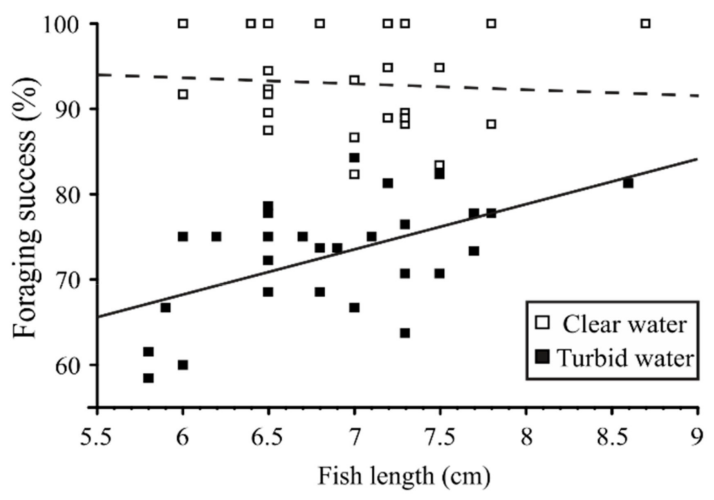

(b)

Figure 2. Relationship between the foraging success of Gymnogeophagus terrapurpura and fish length ( $\mathrm{n}=56$ ) under different water temperature (a) and turbidity conditions (b), after pooling the data from the levels of the factor not shown in each panel. In panel (a), dotted black line, dashed black line, dotted grey line and dashed grey line are the observed (not significant) patterns in 19.2, 22.2, 25.2 and $27.0^{\circ} \mathrm{C}$, respectively. In panel (b), white squares: clear water (3 NTU), black squares: turbid water (100 NTU). Full and dashed lines are the best models fitted for the observed patterns in turbid $(t=3.292 ; P=0.001$; adjusted $\left.\mathrm{R}^{2}=0.27, F_{1,26}=10.75, P=0.002\right)$ and clear waters $(t=-0.383 ; P=0.703)$, respectively.

Table 2. Effects of turbidity and water temperature on the foraging success of predator Gymnogeophagus terrapurpura on amphipod Hyalella curvispina, with fish length (standard length, $\mathrm{cm}$ ) as a continuous predictor variable (GLM results, above section). The significance of the $t$-test of the angular coefficient (slopes derived from the relationship between foraging success and the fish length for each level of both main factors) are also presented in the section below. Statistically significant results are shown in bold.

\begin{tabular}{ccccc}
\hline Main Effects & $\begin{array}{c}\text { Degrees of } \\
\text { Freedom }\end{array}$ & $\begin{array}{c}\text { Means of } \\
\text { Squares }\end{array}$ & $\boldsymbol{F}$ & $\boldsymbol{P}$ \\
\hline Turbidity (TU) & 1 & 0.040 & 12.570 & $\mathbf{0 . 0 0 1}$ \\
Water temperature (WT) & 3 & 0.005 & 1.560 & 0.214 \\
Fish length (FL) & 1 & 0.005 & 1.686 & 0.201 \\
Interaction TU $\times$ WT & 3 & 0.002 & 0.490 & 0.691 \\
Interaction TU $\times$ FL & 1 & 0.020 & 6.247 & $\mathbf{0 . 0 1 7}$ \\
Interaction WT $\times$ FL & 3 & 0.005 & 1.608 & 0.203 \\
Interaction TU $\times$ WT $\times$ FL & 3 & 0.001 & 0.418 & 0.741 \\
Error & 40 & 0.003 & & \\
\hline & & & & \\
\hline Clear Water & & & -0.383 & 0.703 \\
Turbid Water & & & 3.292 & $\mathbf{0 . 0 0 1}$ \\
\hline $19.2^{\circ} \mathrm{C}$ & & & -0.269 & 0.789 \\
$22.2^{\circ} \mathrm{C}$ & & & 0.453 & 0.652 \\
$25.2^{\circ} \mathrm{C}$ & & & 0.833 & 0.170 \\
$27.0^{\circ} \mathrm{C}$ & & & & 0.409 \\
\hline
\end{tabular}

\section{Discussion}

In our short-term experimental simulation of two environmental scenarios predicted as direct and indirect results of climate change, we found no clear effects of heat waves nor of the interaction between heat waves and turbidity pulses on the prey consumption by a subtropical cichlid fish. However, the sudden increase in turbidity had negative consequences on the foraging success of this fish species, but with different magnitudes depending on their body length. A decreased predatory efficiency of fish when visual detection is diminished or prevented was expected, since a similar pattern has been found for several fish species [24,27], including other Cichlid [54] and tropical species [21,55]. 
However, we found that fish with different body lengths consumed a similar amount of prey under clear waters, but in turbid waters, the bigger fish were more efficient than the smaller individuals. Several studies have suggested that the ability of some animal species (e.g., freshwater fish species, such as the guppy Poecilia reticulata Peter, 1859), which adjust their behaviour to cope with variations in their environment (e.g., reduced underwater visibility) [56,57], may be more pronounced in adults than in young individuals $[58,59]$. Due to our choice of experimental individuals, we were able to disentangle the effects of adult predator body size from the effects of ontogenetic variation in feeding performances. Our findings suggest that bigger body sizes may help overcome turbidity-associated limitations in finding and capturing prey. The present study is the first, to our knowledge, to report that the effect of turbidity on predation rate depends upon the predator body size of adult individuals.

After an increase in turbidity, visual predatory individuals need to switch to an alternative sensory modality to locate their prey to compensate for the reduction of visual information [57]. Then, individual differences in the capacity to switch between alternative sensory modalities can emerge and determine foraging success [21]. With our experimental design, we cannot identify the underlying mechanism, such as whether slightly bigger fish have better foraging performances because they might perceive the non-visual stimuli from prey more efficiently than the smaller fish individuals $[32,45,60,61]$. However, regardless of the mechanism behind the higher foraging success of bigger fishes, it only occurred in turbid waters. We suggest that individual differences in feeding performances mediated by predator traits, such as body size, have less impact on fish foraging success in clear waters because predators have no visual impairments to find their prey [21,25] (Figure 3).

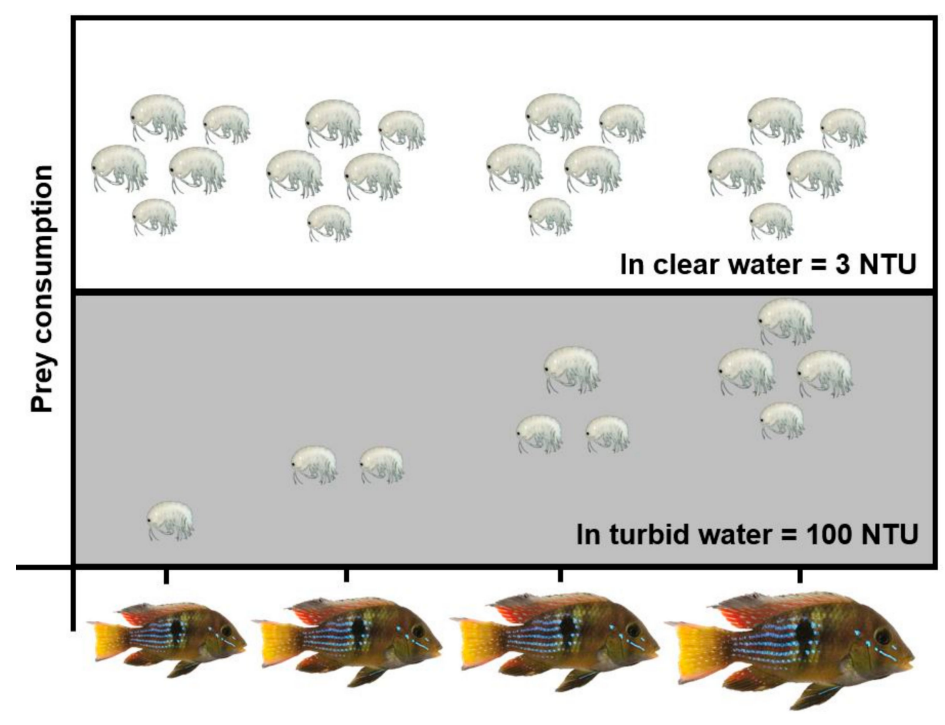

Figure 3. Conceptual figure highlighting that the prey consumption of Gymnogeophagus terrapurpura with different sizes was similar in clear water (white region), but that in turbid water (grey region) bigger fish had better foraging success than smaller ones. Therefore, we demonstrated that the effects of increased turbidity on foraging success depend upon the predator body size.

In contrast to our expectations, the experimental heat wave did not affect the foraging success of $G$. terrapurpura. Predators are usually expected to increase their mobility under higher temperatures $[49,62]$, which could result in more frequent predator-prey encounters $[63,64]$ and potentially higher predation rates [11]. The lack of a significant response may reflect the adaptation of the studied subtropical fish species to the often wide diel and seasonal variations in temperature [12,13], characteristic of shallow water bodies in mid-latitudes, and may also suggest high plasticity of feeding performances in temperature-fluctuating environments. Expectedly, heat waves of longer duration and/or sustained increases in average water temperature would promote stronger effects on different components of fish performance and life-history traits. Alternatively, a possible better escaping performance of 
the prey in warmer waters could compensate for a potential warming-induced increase in foraging success by fish [16]. Supporting the latter hypothesis, more amphipods avoided the co-occurrence with the predator in the treatment with the warmest waters (found in our prey behaviour experiment). These findings may indicate that heat waves could increase both the prey escaping capacity and predator foraging success, potentially making the overall predation rates unchanged under heat waves. Such a response is likely to vary with different predator-prey pairs, and mismatches are likely to occur.

Changes in fish activity with seasonal changes in temperature and turbidity have been described in subtropical shallow lakes [49], highlighting the potential role of lake turbidity as a refuge for small fishes. Short-term effects of warming and of inorganic turbidity, as generated in our study, have received much less attention in the literature. Clearly, short-term microcosm experiments designed to test the potential effects of different aspects of climate change have clear limitations to extrapolate their results to natural, more complex, systems [65]. In our case, such limitations include the small size of the experimental units, the lack of physical heterogeneity (such as the inclusion of refugia other than turbidity) and the lack of biotic interactions other than those under test (such as competition), among others. Such shortcomings could be addressed in future experiments where spatial and temporal scales could be extended with longer-duration experiments, as well as an increase in the body size range of the predatory fish. Under a scenario of increasing frequency of turbidity events, fishes (at the community or population levels) that primarily use non-visual cues, such as olfactory or electrical ones, to detect prey may be favoured by natural selection [66]. Future experiments investigating the effects of extreme meteorological events on predator-prey dynamics should include the competition between visual and non-visual predators and analyse the potential long-term ecological consequences of increases in turbidity level and in the frequency and intensity of heat waves. This issue could also be addressed in long-term field surveys in areas prone to experience increases in turbidity, such as floodplain lakes, as to detect potential changes in species composition and changes in the relative importance of different functional traits within a fish community.

Despite these limitations, our findings suggest that bigger fish individuals may be better prepared to withstand the negative effects of short-term fluctuations in turbidity; and that subtropical ectotherms may have a wide temperature cushion buffering their responses to short-term increases in temperature (at least under the maximum temperatures tested here). Our short-term experiment allowed us to hypothesise that in a future more prone to extreme meteorological events, individual differences (e.g., body sizes) within fish populations could provide a different likelihood of survival and adaptive success, potentially leading to changes at the population and community levels. Also, our findings highlight the importance of experiments that specifically address the potential impacts of extreme meteorological events on different organisms and processes in aquatic ecosystems, since the most often studied effects of changes in mean conditions are not directly translatable.

Author Contributions: B.R.S.F. designed and ran the experiment, processed samples to obtain the data, analysed the data, wrote the manuscript draft and led the manuscript revision. C.C. and A.L.-R. ran the experiment, processed samples to obtain the data and contributed to the manuscript revisions. R.P.M. contributed to the statistical analysis and revisions of the manuscript. F.T.-d.M. contributed to the experimental run and revisions. E.B. contributed to the revisions of the manuscript. M.M. designed and ran the experiment and supervised all manuscript preparation steps. All authors commented on the manuscript.

Funding: This research was funded in part by the "National Council for Scientific and Technological Development (CNPq)", finance code [201890/2014-3] through Brazilian scientific mobility program (Science Without Borders).

Acknowledgments: We thank three anonymous reviewers for their helpful comments on the manuscript. We are grateful to FM Bando, L Gaucher and JM Martinez for their help during the experimental period. MM, FTM, CC and ALR acknowledge the support of "Programa de Desarrollo de las Ciencias Básicas (PEDECIBA)" and "Agencia Nacional de Investigación e Innovación (ANII)", Uruguay. RPM and EB thank the support of the CNPq for providing the research productivity grant.

Conflicts of Interest: The authors declare no conflict of interest. The funders had no role in the design of the study; in the collection, analyses, or interpretation of data; in the writing of the manuscript, or in the decision to publish the results. 


\section{References}

1. IPCC. Summary for Policymakers: Managing the Risks of Extreme Events and Disasters to Advance Climate Change Adaptation. A Special Report of Working Groups I and II of the Intergovernmental Panel on Climate Change; Cambridge University Press: Cambridge, UK, 2012; ISBN 9781139177245.

2. IPCC. Climate Change 2014: Synthesis Report.Contribution of Working Groups I, II and III to the Fifth Assessment Report of the Intergovernmental Panel in Climate Change; IPCC: Geneva, Switzerland, 2014.

3. Marengo, J.A.; Chou, S.C.; Kay, G.; Alves, L.M.; Pesquero, J.F.; Soares, W.R.; Santos, D.C.; Lyra, A.A.; Sueiro, G.; Betts, R.; et al. Development of regional future climate change scenarios in South America using the Eta CPTEC/HadCM3 climate change projections: Climatology and regional analyses for the Amazon, São Francisco and the Paraná River basins. Clim. Dyn. 2012, 38, 1829-1848. [CrossRef]

4. Roland, F.; Huszar, V.; Farjalla, V.; Enrich-Prast, A.; Amado, A.; Ometto, J. Climate change in Brazil: perspective on the biogeochemistry of inland waters. Braz. J. Biol. 2012, 72, 709-722. [CrossRef] [PubMed]

5. Bellard, C.; Bertelsmeier, C.; Leadley, P.; Thuiller, W.; Courchamp, F. Impacts of climate change on the future of biodiversity. Ecol. Lett. 2012, 15, 365-377. [CrossRef] [PubMed]

6. Estes, J.A.; Terborgh, J.; Brashares, J.S.; Power, M.E.; Berger, J.; Bond, W.J.; Carpenter, S.R.; Essington, T.E.; Holt, R.D.; Jackson, J.B.C.; et al. Trophic Downgrading of Planet Earth. Science 2011, 333, 301-306. [CrossRef] [PubMed]

7. Brown, J.H.; Gillooly, J.F.; Allen, A.P.; Savage, V.M.; West, G.B. Toward a metabolic theory of ecology. Ecology 2004, 85, 1771-1789. [CrossRef]

8. McKenzie, D.; Claireaux, G. The effects of environmental factors on the physiology of aerobic exercise. Fish Locomot. Eco-Ethol. Perspec. 2010, 296-332. [CrossRef]

9. Nowicki, J.P.; Miller, G.M.; Munday, P.L. Interactive effects of elevated temperature and CO2 on foraging behavior of juvenile coral reef fish. J. Exp. Mar. Biol. Ecol. 2012, 412, 46-51. [CrossRef]

10. Doyle, S.R.; Momo, F.R. Effects of body weight and temperature on the metabolic rate of Hyalella curvispina Shoemaker, 1942 (Amphipoda). Crustaceana 2009, 82, 1423-1439. [CrossRef]

11. Pink, M.; Abrahams, M.V. Temperature and its impact on predation risk within aquatic ecosystems. Can. J. Fish. Aquat. Sci. 2015, 73, 869-876. [CrossRef]

12. Kingsolver, J.G.; Huey, R.B. Evolutionary analyses of morphological and physiological plasticity in thermally variable environments. Am. Zool. 1998, 38, 545-560. [CrossRef]

13. Sørensen, J.G.; Loeschcke, V. Natural adaptation to environmental stress via physiological clock-regulation of stress resistance in Drosophila. Ecol. Lett. 2002, 5, 16-19. [CrossRef]

14. Wegner, K.M.; Kalbe, M.; Milinski, M.; Reusch, T. Mortality selection during the 2003 European heat wave in three-spined sticklebacks: Effects of parasites and MHC genotype. BMC Evol. Biol. 2008, 8, 124. [CrossRef] [PubMed]

15. Leicht, K.; Jokela, J.; Seppälä, O. An experimental heat wave changes immune defense and life history traits in a freshwater snail. Ecol. Evol. 2013, 3, 4861-4871. [CrossRef] [PubMed]

16. Öhlund, G.; Hedström, P.; Norman, S.; Hein, C.L.; Englund, G. Temperature dependence of predation depends on the relative performance of predators and prey. Proc. R. Soc. B Biol. Sci. 2014, 282, 20142254. [CrossRef] [PubMed]

17. Seifert, L.I.; Castro, F.; Marquart, A.; Gaedke, U.; Weithoff, G.; Vos, M. Heated relations: Temperature-mediated shifts in consumption across trophic levels. PLOS ONE 2014, 9, 195. [CrossRef]

18. Kirk, J.T.O. Effects of suspensoids (turbidity) on penetration of solar radiation in aquatic ecosystems. Hydrobiologia 1985, 125, 195-208. [CrossRef]

19. Roach, K.A.; Winemiller, K.O. Hydrologic regime and turbidity influence entrance of terrestrial material into river food webs. Can. J. Fish. Aquat. Sci. 2015, 72, 1099-1112. [CrossRef]

20. Sousa, W.T.Z.; Thomaz, S.M.; Murphy, K.J.; Silveira, M.J.; Mormul, R.P. Environmental predictors of the occurrence of exotic Hydrilla verticillata (L.f.) Royle and native Egeria najas Planch. in a sub-tropical river floodplain: The Upper River Paraná, Brazil. Hydrobiologia 2009, 632, 65-78. [CrossRef]

21. Figueiredo, B.R.S.; Mormul, R.P.; Chapman, B.B.; Lolis, L.A.; Fiori, L.F.; Benedito, E. Turbidity amplifies the non-lethal effects of predation and affects the foraging success of characid fish shoals. Freshw. Biol. 2016, 61, 293-300. [CrossRef]

22. Aksnes, D.L.; Utne, A.C.W. A revised model of visual range in fish. Sarsia 1997, 82, 137-147. [CrossRef] 
23. Horppila, J.; Nurminen, L. Effects of submerged macrophytes on sediment resuspension and internal phosphorus loading in Lake Hiidenvesi (southern Finland). Water Res. 2003, 37, 4468-4474. [CrossRef]

24. Ranåker, L.; Jönsson, M.; Nilsson, P.A.; Brönmark, C. Effects of brown and turbid water on piscivore-prey fish interactions along a visibility gradient. Freshw. Biol. 2012, 57, 1761-1768. [CrossRef]

25. Higham, T.E.; Stewart, W.J.; Wainwright, P.C. Turbulence, Temperature, and Turbidity: The ecomechanics of predator-prey interactions in fishes. Integr. Comp. Biol. 2015, 55, 6-20. [CrossRef] [PubMed]

26. Wishingrad, V.; Musgrove, A.B.; Chivers, D.P.; Ferrari, M.C.O. Risk in a changing world: Environmental cues drive anti-predator behaviour in lake sturgeon (Acipenser fulvescens) in the absence of predators. Behaviour 2015, 152, 635-652. [CrossRef]

27. Abrahams, M.; Kattenfeld, M. The role of turbidity as a constraint on predator-prey interactions in aquatic environments. Behav. Ecol. Sociobiol. 1997, 40, 169-174. [CrossRef]

28. Parmesan, C.; Root, T.L.; Willig, M.R. Impacts of extreme weather and climate on terrestiral biota. Bull. Am. Meteorol. Soc. 2000, 81, 443-450. [CrossRef]

29. Ferrari, M.C.O.; Ranåker, L.; Weinersmith, K.L.; Young, M.J.; Sih, A.; Conrad, J.L. Effects of turbidity and an invasive waterweed on predation by introduced largemouth bass. Environ. Biol. Fishes 2014, 97, 79-90. [CrossRef]

30. Dangles, O.; Magal, C.; Pierre, D.; Olivier, A.; Casas, J. Variation in morphology and performance of predator-sensing system in wild cricket populations. J. Exp. Biol. 2005, 208, 461-468. [CrossRef] [PubMed]

31. Ohlberger, J. Climate warming and ectotherm body size-from individual physiology to community ecology. Funct. Ecol. 2013, 27, 991-1001. [CrossRef]

32. Breck, J.E.; Gitter, M.J. Effect of fish size on the reactive distance of bluegill (Lepomis macrochirus) Sunfish. Can. J. Fish. Aquat. Sci. 1983, 40, 162-167. [CrossRef]

33. Miller, T.J.; Crowder, L.B.; Rice, J.A.; Marschall, E.A. Larval size and recruitment mechanisms in fishes: Toward a conceptual framework. Can. J. Fish. Aquat. Sci. 1988, 45, 1657-1670. [CrossRef]

34. Lundvall, D.; Svanbäck, R.; Persson, L.; Byström, P. Size-dependent predation in piscivores: Interactions between predator foraging and prey avoidance abilities. Can. J. Fish. Aquat. Sci. 1999, 56, 1285-1292. [CrossRef]

35. Biro, P.A.; Beckmann, C.; Stamps, J.A. Small within-day increases in temperature affects boldness and alters personality in coral reef fish. Proc. R. Soc. B Biol. Sci. 2010, 277, 71-77. [CrossRef] [PubMed]

36. Teixeira-de Mello, F.; de Oliveira, V.A.; Loverde-Oliveira, S.M.; Huszar, V.L.M.; Barquín, J.; Iglesias, C.; Silva, T.S.F.; Duque-Estrada, C.H.; Silió-Calzada, A.; Mazzeo, N. The structuring role of free-floating plants on the fish community in a tropical shallow lake: An experimental approach with natural and artificial plants. Hydrobiologia 2016, 778, 167-178. [CrossRef]

37. Teixeira-de Mello, F.; Vidal, N.; Eguren, G.; Loureiro, M. Length-weight relationships of 21 fish species from the lower section of the Santa Lucía river basin (Canelones-Montevideo, Uruguay). J. Appl. Ichthyol. 2009, 25, 491-492. [CrossRef]

38. López-Rodríguez, A.; Silva, I.; de Ávila-Simas, S.; Stebniki, S.; Bastian, R.; Massaro, V.M.; Pais, J.; Tesitore, G.; Teixeira-de Mello, F.; D'Anatro, A.; et al. Diets and trophic structure of fish assemblages in a large and unexplored subtropical river: The Uruguay River. Water 2019, 11, 1374. [CrossRef]

39. Loureiro, M.; Zarucki, M.; Malabarba, L.R.; González-Bergonzoni, I. A new species of Gymnogeophagus Miranda Ribeiro from Uruguay (Teleostei: Cichliformes). Neotrop. Ichthyol. 2016, 14, e150082. [CrossRef]

40. Hartz, S.M.; Bruschi, J.W.; Formehl, M.V. Idade e crescimento de Gymnogeophagus lacustris Reis \& Malabarba, um Cichlidae endêmico da bacia hidrográfica do Rio Tramandaí, Rio Grande do Sul, Brasil. Rev. Bras. Zool. 1998, 15, 605-613. [CrossRef]

41. Meerhoff, M.; Iglesias, C.; Teixeira-de Mello, F.; Clemente, J.M.; Jensen, E.; Lauridsen, T.L.; Jeppesen, E. Effects of habitat complexity on community structure and predator avoidance behaviour of littoral zooplankton in temperate versus subtropical shallow lakes. Freshw. Biol. 2007, 52, 1009-1021. [CrossRef]

42. Kullander, S.O. Cichlidae (Cichlids). In Checklist of the Freshwater Fishes of South and Central America, 1st ed.; Reis, R.E., Kullander, S.O., Ferraris, C.J.J., Eds.; EDIPUCRS: Porto Alegre, Brazil, 2003; pp. 605-654.

43. Yafe, A.; Loureiro, M.; Scasso, F.; Quintans, F. Feeding of two cichlidae species (Perciformes) in an hypertrophic urban lake. Iheringia Sér. Zool. 2002, 92,73-79. [CrossRef] 
44. González-Bergonzoni, I.; Jeppesen, E.; Vidal, N.; Teixeira-de Mello, F.; Goyenola, G.; López-Rodriguez, A.; Meerhoff, M. Potential drivers of seasonal shifts in fish omnivory in a subtropical stream. Hydrobiologia 2016, 768, 183-196. [CrossRef]

45. Scharf, F.S.; Juanes, F. Predator size-prey size relationships of marine fish predators: Interspecific variation and effects of ontogeny and body size on trophic-niche breadth. Mar. Ecol. Prog. Ser. 2000, 208, 229-248. [CrossRef]

46. Galassi, M.E.; Franceschini, M.C.; Neiff, A. Population estimates of Hyalella curvispina Shoemaker (Amphipoda) in aquatic vegetation of Northeastern Argentinian ponds. Acta Limnol. Bras. 2006, 18, 101-108. [CrossRef]

47. Yorojo Moreno, V.; García, I.; Maroñas, M.E.; Colautti, D.C. Feeding of Gymnogeophagus meridionalis (Osteichthyes, Cichlidae) in an urban stream. Rev. Mus. Argent. Cienc. Nat. Nueva Ser. 2017, 19, 93-100. [CrossRef]

48. Teixeira-de Mello, F.; Meerhoff, M.; Pekcan-Hekim, Z.; Jeppesen, E. Substantial differences in littoral fish community structure and dynamics in subtropical and temperate shallow lakes. Freshw. Biol. 2009, 54, 1202-1215. [CrossRef]

49. Gelós, M.; Teixeira-de Mello, F.; Goyenola, G.; Iglesias, C.; Fosalba, C.; García-Rodríguez, F.; Pacheco, J.P.; García, S.; Meerhoff, M. Seasonal and diel changes in fish activity and potential cascading effects in subtropical shallow lakes with different water transparency. Hydrobiologia 2010, 646, 173-185. [CrossRef]

50. Colombo, J.C.; Skorupka, C.N.; Bilos, C.; Tatone, L.; Cappelletti, N.; Carolina Migoya, M.; Astoviza, M.; Speranza, E. Seasonal and inter-annual variability of water quality in the Uruguay River, Argentina. Hydrol. Sci. J. 2015, 60, 1155-1163. [CrossRef]

51. Wheeler, B.; Torchiano, M. Package 'lmPerm'. 2016. Available online: ftp://ftp.math.ethz.ch/sfs/pub/Software/ R-CRAN/web/packages/lmPerm/lmPerm.pdf (accessed on 4 July 2019).

52. Dowdy, S.; Wearden, S.; Chilko, D. Statistics for research; John Wiley and Sons: Somerset, NJ, USA, 2004.

53. Quinn, G.P.; Keough, M.J. Experimental Design and Data Analysis for Biologists; Cambridge University Press: Cambridge, UK, 2002.

54. Schwalbe, M.A.B.; Bassett, D.K.; Webb, J.F. Feeding in the dark: Lateral-line-mediated prey detection in the peacock cichlid Aulonocara stuartgranti. J. Exp. Biol. 2012, 215, 2060-2071. [CrossRef]

55. Figueiredo, B.R.S.; Mormul, R.P.; Benedito, E. Non-additive effects of macrophyte cover and turbidity on predator-prey interactions involving an invertivorous fish and different prey types. Hydrobiologia 2013, 713, 23-30. [CrossRef]

56. Dingemanse, N.J.; Both, C.; Drent, P.J.; Tinbergen, J.M. Fitness consequences of avian personalities in a fluctuating environment. Proc. R. Soc. Biol. Sci. 2004, 271, 847-852. [CrossRef]

57. Chapman, B.B.; Morrell, L.J.; Tosh, C.R.; Krause, J. Behavioural consequences of sensory plasticity in guppies. Proc. R. Soc. Biol. Sci. 2010, 277, 1395-1401. [CrossRef]

58. Polverino, G.; Ruberto, T.; Staaks, G.; Mehner, T. Tank size alters mean behaviours and individual rank orders in personality traits of fish depending on their life stage. Anim. Behav. 2016, 115, 127-135. [CrossRef]

59. Rothen, D.; Curtis, E.; Yanong, R. Tolerance of yolk sac and free-swimming fry of the zebra danio Brachydanio rerio, black tetra Gymnocorymbus ternetzi, Buenos Aires tetra Hemigrammus caudovittatus, and blue gourami Trichogaster trichopterus to therapeutic doses of formalin and sodium chloride. J. Aquat. Anim. Health 2002, 14, 204-208.

60. Kingsolver, J.G.; Pfennig, D.W. Individual-level selection as a cause of Cope's rule of phyletic size increase. Evolution 2007, 58, 1608-1612. [CrossRef] [PubMed]

61. Hone, D.W.E.; Benton, M.J. The evolution of large size: How does Cope's Rule work? Trends Ecol. Evol. 2005, 20,4-6. [CrossRef] [PubMed]

62. Vucic-Pestic, O.; Ehnes, R.B.; Rall, B.C.; Brose, U. Warming up the system: Higher predator feeding rates but lower energetic efficiencies. Glob. Chang. Biol. 2011, 17, 1301-1310. [CrossRef]

63. Anderson, M.T.; Kiesecker, J.M.; Chivers, D.P.; Blaustein, A.R. The direct and indirect effects of temperature on a predator-prey relationship. Can. J. Zool. 2001, 79, 1834-1841. [CrossRef]

64. Dell, A.I.; Pawar, S.; Savage, V.M. Temperature dependence of trophic interactions are driven by asymmetry of species responses and foraging strategy. J. Anim. Ecol. 2013, 83, 70-84. [CrossRef] 
65. Stewart, R.I.A.; Dossena, M.; Bohan, D.A.; Jeppesen, E.; Kordas, R.L.; Ledger, M.E.; Meerhoff, M.; Moss, B.; Mulder, C.; Shurin, J.B.; et al. Mesocosm experiments in ecological climate change research. Adv. Ecol. Res. 2013, 48, 71-181. [CrossRef]

66. French, W.E.; Graeb, B.D.S.; Chipps, S.R.; Klumb, R.A. Vulnerability of age-0 pallid sturgeon Scaphirhynchus albus to predation; effects of predator type, turbidity, body size, and prey density. Environ. Biol. Fish. 2014, 97, 635-646. [CrossRef]

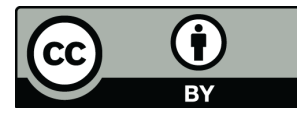

(C) 2019 by the authors. Licensee MDPI, Basel, Switzerland. This article is an open access article distributed under the terms and conditions of the Creative Commons Attribution (CC BY) license (http://creativecommons.org/licenses/by/4.0/). 